\title{
DEVELOPING CALF (CONTEXTUAL, ATTRACTIVE, LOGICAL, AND FUN) MEDIA TO TEACH READING FOR YOUNG LEARNERS
}

\author{
Mahayanti, N. W. S. \\ English Language Education \\ Ganesha University of Education \\ Singaraja, Indonesia \\ e-mail: mahayantisurya@yahoo.co.id
}

\begin{abstract}
This study aims at developing media for group work activity in teaching reading for elementary school students. It was conducted in SD 4 Kaliuntu located in Buleleng. Observation sheets, teacher questionnaires, students' questionnaires, and rubric were used to gain the data. Sugiyono's R\&D model was employed as the research procedures. The data obtained were quantitatively and qualitatively analyzed. From the result, it was found that the media could be developed by conducting several procedures, such as preliminary observation, syllabus analysis, library research, media development, experts' judgment, and field test. Through those procedures, excellent prototype media named CALF were designed. As the implication, group work could be done effectively in that school setting.
\end{abstract}

Keywords: contextual, media, reading

\section{INTRODUCTION}

As one of provinces in Indonesia that has a large tourism industry, Bali requires English as a basic requirement that needs to be improved in line with the progress of tourism industry. The implementation of regional autonomy (Regulation No. 22 of 1999 and Regulation No. 32 of 2004) in which there is a transfer of authority from the central government to the local governments makes the government of Bali easier in accommodating the needs of English teaching which has been increasing gradually. In accordance to Bali Governor's decision letter about the local content curriculum in Bali Province, English becomes one of the local content required besides Balinese language and manners subject. Teaching English as local content in Bali aims at providing knowledge and skills of English for the learners in order to make them able to support regional and national development. The skills that are provided in teaching English include listening, speaking, reading, and writing.

From those four skills, reading has arisen as the fundamental skill upon which all formal education depends (Moats: 1999). Pang et al. (2003) said that learning to read is an important educational goal. For both children and adults, the ability to read opens up new worlds and opportunities. It enables students to gain new knowledge, enjoy literature, and do everyday things that are part and parcel of modern life, such as, reading the newspapers, job listings, instruction manuals, maps and so on.

Considering the importance of reading in teaching English, Indonesia government provides sets of standard competency and basic competency as the minimal requirements that should be achieved by the students in reading skills. Based on BSNP (2006), reading in elementary school includes: 1) reading written sentences/ very simple texts with good pronunciation, pitch, and intonation, and 2) understanding the meaning of written sentences/ very simple texts with accurate, fluent, and understood way.

From those requirements of teaching English in elementary school, reading in elementary school should be done in a natural way because teaching young learners is different from teaching adults. Young children learn from everything they do (Carlton, 2003). They are naturally curious; they want to explore and discover. If Their Explorations bring pleasure or success, they will want to learn more earnest. And the 
key in making young learners succeed in learning is by creating fun and enjoyable activity in their learning process.

Based on observations done by the researcher when doing practice teaching in SD 1 Banjar Jawa, teaching reading was still centered on the teacher. The teacher explained and introduced some new vocabularies and asked students to read a paragraph in the textbook. After that, the students were only assigned to answer the tasks in textbook without being given the opportunity to move further. This teaching method was continuing in every meeting. Several students who were interviewed by the researcher said that teaching reading created boredom situation for them.

Besides, the teaching reading method was still traditional, the students also seemed unmotivated in learning. That low motivation can be caused by the limited use of media. During one month's observation, media, which were in form of realia, were only used once when teaching 'Things in the Classroom' and were even only used in order to introduce some vocabulary related with 'Things in the Classroom'.

Creating a learning atmosphere which is enjoyable is the key for solving those problems above (Scott \& Ytreberg, 1990). Learning, which was boring because of focusing on teacher as the center of process, should be changed to be focused on student/student-centered. Student-centered learning is an approach to education focusing on the needs of the students, rather than those of others involved in the educational process, such as teachers and administrators (Rahardjo \& Pongtuluran, 2001). By conducting students-centered learning, the students are expected to participate actively in building their own knowledge, attitudes, and manners so then they can get their own deep learning and deep understanding which can make them become more qualified latter on (Afiatin, 2007).

However, group work, as one strategy that can give chance for the students to be actively in learning, is one way that can be used for applying students-centered approach. By working together in a group, students, especially young learners can feel safe, because they will not worry being pointed to answer questions. Besides, group work will also give more chances for the students to be more active in teaching and learning process. Group work can help students to become more active in their learning (Killen, 1996). When working with peers in a group, students are encouraged to articulate their ideas and question the ideas of others.

In accordance to the above explanations, students' low motivation in learning can be improved through the use of interesting media while working in group. As stated in Supplement Module by Ministry of National Education Department, Ruis et al. (2009) stated that the major problems of teaching English in class seem that learners are not interested in studying. In order to make them interested in learning, and make them motivate in learning, it is suggested that English teachers should use media in their teaching and learning process and the class will be more meaningful and enjoyable.

It is also supported by Riana (2007) who stated that in order to help the students in gaining meaningful learning experiences, the role of media cannot be neglected. She added that media have some functions, one of them is to create a high motivation in learning and concrete interaction between students-teacher and also students-students. Hence, Sadiman et al. (2002) stated that because of the role of media, it can arise the learners' thought, feeling, and interests to gear the students' learn.

Unfortunately, designing interesting media which can be used for group work activity in teaching reading is not easy for teachers of elementary school, especially in Buleleng District. For that reason, this study was a preliminary study which was focused on designing media for group work activity in teaching reading for elementary school grade five. That media could be used for two semesters. The development of that media was designed based on the problems faced in real situation (based on the preliminary observation), results of syllabus (school-based syllabus) analysis, the criteria of good media, and some empirical studies. Thus, it was still considered as a prototype which needed further development and field test to meet the needs of the students and teachers in other schools.

\section{METHODS}

The subject of this study was the fifth grade English teachers and students in SD 4 Kaliuntu, Buleleng. Fifth grade students were chosen because the students in that level have known enough vocabularies to support them in understanding very simple reading text. Besides, Scott \& Ytreberg (1990) stated that 
students in that age, 9-10 years old, already have ability in working with and learning from others. The object of this study was media in the form of board for group work activity which contained materials that were organized in such a way. It gave flexibility for the students to use and helped them to improve their reading ability. The media construction followed the criteria for effective media for children by Zaman \& Eliyawati (2010) and characteristics good material by Tomlinson.

Since this present study had purpose in developing the new media for group work activity in teaching reading, Research and Development $(\mathrm{R} \& \mathrm{D})$ design was used. $\mathrm{R} \& \mathrm{D}$ refers to a research method which is used to develop or produce a certain new product and try out the effectiveness of that product (Sugiyono: 2009). Sugiyono (2009) also said that to be able to produce a new product, the need analysis is really needed as the basis of the development process. While, in order to try out the effectiveness of that product, researches in trying out that product' effectiveness should be conducted. It is why R\&D is a longitudinal research (in multi-stages or even multi-years). Considering the complexity of $R \& D$, this study, then, was limited on the designing a new prototype product of media which could be used for group work activity teaching reading. Because of that reason, the research design was elaborated in order to make it easier to understand from which it was developed into a new design shown in Figure 1.

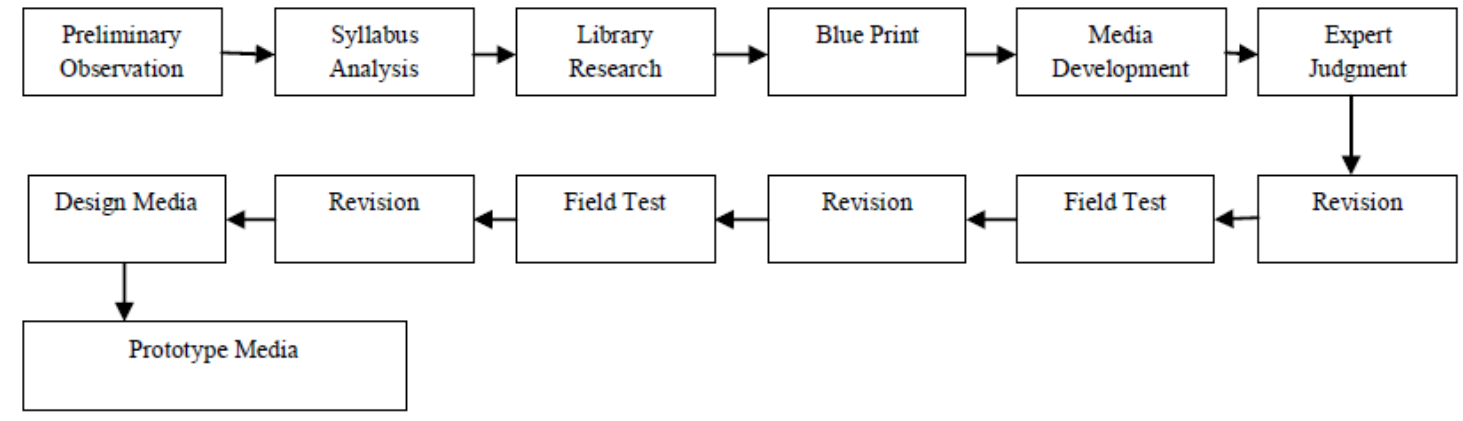

Figure 1. Research Design

Considering the figure 1 previously, there were some instruments needed to gain data in each procedure, they are observation sheets, teacher questionnaires, students' questionnaires, and rubrics. Those data, then, were mostly analyzed descriptively. The data obtained from observation and questionnaires conducted in preliminary observation were described in order to know the problem faced in real situation. Then, it was continued by analyzing the data from syllabus analysis step. Those data, then, were analyzed descriptively in order to know the basic requirement of teaching reading for elementary school grade five. After that, library research was conducted in order to gain the theories and empirical studies which were used as supporting basis in this study. That data were also described descriptively. In the development of media, there were some process of data analysis, namely analysis of media validity (analyzed descriptively), analysis of media practical.

\section{FINDINGS AND DISCUSSION}

The first procedure done in this study was preliminary observation with pupose to know kinds of media that were usually used by the teacher i. For that purpose, three kinds of instruments were used, observation sheet, teacher's questionnaire, and students' questionnaire. From those three instruments, besides finding out kinds of media used by the teacher in teaching listening, there were also kinds of teaching strategy used and their effectiveness, feeling of the students toward that strategy, and things that students like and dislike in learning English in the class found.

From observation conducted in SD 4 Kaliuntu, it was found that there was one commonly strategy used in teaching reading, direct instruction. The teacher of that school simply explained the material and asked the students to take some notes in their notebook. After explaining the material, the teachers asked some questions to recall their understanding, but only some students who could participate in answering those questions. 
Besides, the media used in that school were not varying. The teacher in that school just used board to write down some vocabularies, phrases, and sentences on the board and asked the students to read and take some notes about that. Actually, the teacher could maximize the use of that board by dividing it into four parts and wrote from the left part until the right part, so the students could know which one was the first and which one was the next thing that they had to read. But, by looking at the characteristics of students who like to do something new, variation of media were really needed.

Considering that fact, the teacher in SD 4 Kaliuntu, added one kind of media that was drawing. At that time, the teacher taught about foods and drinks, and she drawn some kinds of foods like bread, burger, and ice cream. From that media, some students could guess the name of those foods and drink in English easier. Unfortunately, the pictures drawn by the teacher were not so clear, so the other students toke more time to guess what the pictures were really about. From the situation seen at that time, it could be said that some students were enthusiastic enough in learning, even with limited media.

Generally, the teaching and learning process in that school in city was already good, because the students like it. But, it would be much better if there were some variations in teaching strategy used to maximize the participation of all students and media used to make the students more fun and enjoying the process. The only strategy used in teaching reading was direct instruction. It meant that the teacher there still used conventional way in teaching young learners. In line with the strategy used, the media used was also limited in only one kind of media. Media, as a thing that could arise the learners' thought, feeling, and interests to gear the students' learn, becomes something that is very important in teaching and learning process.

From the results of the observation above, it could be concluded that the process of teaching and learning in that school were still convensional. They had some limitations, both in the case of strategy and media. Some improvements were still needed to make it better because as stated by Ruis et al. (2009) that In order to make them interested learning, and make them motivate in learning, it is suggested that English teachers should use innovative media in their teaching and learning process and the class will be more meaningful and enjoyable. Because of that reason, there were creative strategy and innovative media needed in order to raise students' motivation in learning.

Teacher questionnaire was another kind of instrument used in preliminary observation. From questionnaire filled by the teacher there, it was found that the strategy used in teaching reading were more than one strategy. In SD 4 Kaliuntu, the teacher used 4 kinds of strategies in teaching reading, discussion, group work, cooperative learning, and performance activity. In the questionnaire, it was also said that those strategies were effective enough in teaching reading for the students in that level. By doing discussion, group work, and cooperative learning, students were able to share their thinking and idea with the other friends. Thus, by doing performance activity, the students were given chances to practice their language in front of the class. For the teacher, those kinds of strategies in teaching could motivate the students in learning. It was indicated by the activeness of the students in joining every teaching and learning activity.

Unfortunately, the strategies that were good were not supported by the use of attractive media. From the questionnaire filled by the teacher in SD 4 Kaliuntu, it was found the only media used in teaching the students was only blackboard. The teacher simply wrote down all the material on the board and asked the students to re-write it in their notebooks. It was also said that the use of blackboard was not too effective. But, because the limitation of the school and the teacher herself, other kinds of media could not be used in order to make the learning becoming more fun. However, it was also found in the questionnaire that sometimes, most students were not motivated enough in re-writing all the things written on the board. To make it simpler, the following table shows the strategies used in that school based on the questionnaire filled by the teachers in those schools.

As the last instrument used in preliminary observation in this research, students' questionnaire played a very important role in triangulating the results of observation done by the researcher and the questionnaire filled by the teacher in that school setting. By asking the students filling the questionnaire, it would be found the fact about their feeling about the teaching and learning process. The distribution of the questionnaire had purposes to know students' feeling about the teaching and learning process, the way of 
the teacher teaching, the things that they like and dislike in learning English, and the kinds of media used by the teacher while they learn in the class.

From the questionnaire filled by the students of SD 4 Kaliuntu, it was found that, in the case of their feeling toward the teaching and learning process, there were $34.04 \%$ of the students who said that they liked the teaching and learning process very much. $44.44 \%$ of them said that the teaching and learning process was fun and they liked it. The rest students, which were about $18.52 \%$, said that they felt the teaching and learning process in their class was not too interesting. From that result, it could be concluded that most of the students said that the process of their learning in the classroom was fun. The following chart shows the comparison of the students feeling.

The same fact was found from the second question in the questionnaire, which was about the way of their teacher's teaching. Most of the students, which was $48.15 \%$ of the students, said that the way of their teacher's teaching was fun. Another student, $29.63 \%$, said that they really liked the way of their teacher's teaching in the classroom. The rest students, $22.22 \%$, said that the teaching was not too fun. For those six students, it was not too interesting to learn English in that way. The following chart shows the comparison of the students feeling.

The third question was not too different with the second one. It asked about the students feeling toward the way of their teacher's teaching, whether they liked it of not. The same as the previous question, most of the students, $48.15 \%$, liked the way of their teacher's teaching, while the others $33.33 \%$ of the students said that they really liked it. The rest students, which were $18.52 \%$, said that they felt common in learning English with that kind of style. The following chart shows the comparison of the students feeling.

The next question in the questionnaire was about kinds of the media that commonly used by the teacher in teaching English. From the questionnaire filled by 27 students in that school, it was found that blackboard was the most commonly used media. $92.59 \%$ of the students said that blackboard was a very commonly used media in teaching and learning process conducted in the classroom. $7.41 \%$ of them said that it was usual to use blackboard as a supporting media in the classroom. Thus, there were also four kinds of media that rarely used by the teacher in teaching English, poster, audio, OHP, and LCD. The other kinds of media, pictures, realia, drawing, and table were the media which were only used in some conditions only.

The next other two questions were about the things that they liked and disliked in learning English in the classroom. For the thing that they liked, most students in SD 4 Kaliuntu liked to learn English by using game. $81.48 \%$ of them said that they could enjoy the teaching and learning process while they were asked to do such kind of English games. Besides, $7.41 \%$ of the students said that they liked to learn English vocabulary. Another 7.41\% liked everything that they got when learning English and the rest, 3.70\% of the students, liked to speak, write, and do game in learning English. The following chart shows the comparison of the students feeling.

Even though there were $44.44 \%$ of the students who said that there was nothing that they disliked, there were also many things that the other students did not like in learning English. $25.93 \%$ of them did not like learning English when the teacher was angry and $18.52 \%$ did not like learning English when they were punished by the teacher. The rest, $11,11 \%$ of the students, did not like learning English because it was difficult. The following chart shows the comparison of the students feeling.

From those three findings above, observation, teacher's questionnaire, and students' questionnaire, it could be concluded that the teaching and learning process in that school were still convensional. Direct instruction was the only strategy used there. Hence, there were no varieties of strategy that could increase the motivation of the students in learning. It was also found that the existing media in that school was categorized as average media. Because of those findings, other kinds of strategy and media were needed in that school in helping the students being active in learning. It was also needed in that school to create fun and enjoyable atmosphere since the students are still categorized as young learners. In order to create fun and enjoyable atmosphere, innovative media become a must to be used. It is supported by Soekartiwi (1996) who stated that there are some advantages of using media in teaching-learning process, like increasing the learners' motivation, avoiding the learners bored, making the learners easy to understand the instructional material, and making the teaching learning process more systematic. 
The second and third procedure of this study was done in order to know kinds of media that could help the students of elementary school in Buleleng District improving their listening comprehension. For that reason, two ways of collecting the data were done, syllabus analysis and library research. Those two kinds of data collection were needed in order to know the basic requirements that should be achieved by the students and could be developed as parts of the media and supporting materials designed, the theory of characteristics of good media and supporting materials that could help the students in improving their reading and could be used in group work activity, and some empirical study about developing media.

Syllabus was needed to know the basic requirement that should be achieved by elementary school students in order to be said as competence students. The Government has designed the list of basic requirements in the curriculum (school-based curriculum) for elementary school which, then, were developed by the schools as syllabus. Since the aim of syllabus development is to enable teachers to elaborate the Basic Competence from the Standard of Content and state indicators of the Basic Competence, to map the materials into appropriate scope and sequence of materials, to elaborate the evaluation into types and kinds of evaluation, and learning process into learning experiences (Muhaimin, \& Prabowo, 2008), the consideration of competency standards, basic competencies, and indicators of reading skill should be taken a part. That was conducted in order to produce appropriate teaching media and supporting materials which meet the criteria of school-based syllabus. In analyzing the syllabus, the teacher in the school setting was involved. That teacher filled the checklist, which was designed based on the school based curriculum and was provided by the researcher. From that checklist, the teacher in that school chose the indicators that were appropriate to be developed in the media that would be designed.

From the result of the check list, it could be seen that the teacher in that school said that the entire indicators in the syllabus should be achieved by using the media that would be developed. It meant that all the topics in the syllabus should be included in the supporting material in the media that would be designed. It was hoped that by using the media that would be developed, the students could achieve all the indicators, finding the information in the texts and reading aloud the texts, in all units (Identity, Daily Activities, School Environment, Family, House, Clothes, Animals, Food and Drinks, Parts of Human Body, and Public Places).

Library research were also needed in order to find out the theories of characteristics of good media in teaching young learners and characteristics of media that could be used in group work activity. From the library research conducted, it was found that a good media is a media that can give some advantages in teaching-learning process. Besides, there was also found a theory from Zaman who proposed a format for assessing media draft to be said as a good media.

From the library research done, it was also found a good media that have already designed in Germany. That media is called LOGICO. The idea of that media is good. As an educative playing tool, that media can make the students playing and learning in one time. The form and the size of the media are also good to be used as individual and group media. Actually the media have been produced in Indonesia under the licence of Kanisius Media. But, unfortunately, the supporting materials of that media are not designed based on the curriculum in this country. Because of that reason, it was decided to design a new media which adapted the idea of that excisting media. The media designed would be in form of board which was supported by some supporting materials based on the ten topics suggested in the syllabus.

As the next procedures of this study, drafting the media and the supporting materials based on the syllabus analysis and library research, designing the media based on the draft/blue print, consulting with supervisors and some experts, and revising was conducted in order to designed a prototype media for group work activity in teaching listening for elementary school students in Buleleng District.

Before designing the draft of that media, a blue print was designed by considering and combining the problems faced from the preliminary observation, the results of syllabus analysis, and also the theories of appropriate/good media, ways of teaching young learner, and empirical studies. Thus, the blue print of the media being developed was carefully mapped and revised by considering and analyzing comprehensive data and information from the identified problems, syllabus analysis, theory of good media, and supporting empirical studies. The media was in the form of board with appropriate size to be used in a group which was consist of 4-5 students. That board was made by using good quality of wood in order to make it strong and 
could be used for long time. There was space that could be used to insert the supporting materials which could be changed based on the topic and the need. That media would also be completed with some magnets to make the pin able to move and stick based on the supporting material used.

Besides that media, there were also some supporting materials that had been designed. The materials were divided into ten topics, based on the topics required by the syllabus, in which each topic consisted of seven sheets. In each topic, there were some sheets about the vocabulary related with the topic, some sheets about filling the blank text, and some sheets about comprehension text with the questions. After accomplishing the blue print of the media, some related resources and references, including texts and pictures, were collected. By making use the result of the analysis conducted when planning and designing the blue print, media for group work was carefully and systematically developed.

The media was made in a workshop located in Pengelatan Village based on the blue print/picture designed by the researcher. Since that media was used in the group work activity, in which in each class there would be 6-10 groups, so there were 10 board produced with a purpose to make the media being able to be used in the field test. The size of the boards were made as proportional as possible, $34 \mathrm{~cm}$ length and $25 \mathrm{~cm}$ wide, to be used as a media for a group of 4-5 students. 1 month was needed in order to finish the media with appropriate color.

Since the media was designed with a purpose to help the fifth grade students of elementary school in reading English words, sentences, or even very simple texts, and by considering the characteristics of good media, this media was named as CALF. CALF stands for Contextual Attractive Logic Fun. That name was chosen because the media could give contextual texts with attractive color and pictures which could be applied in logic and fun situation. The concrete illustration could be seen in the following picture.

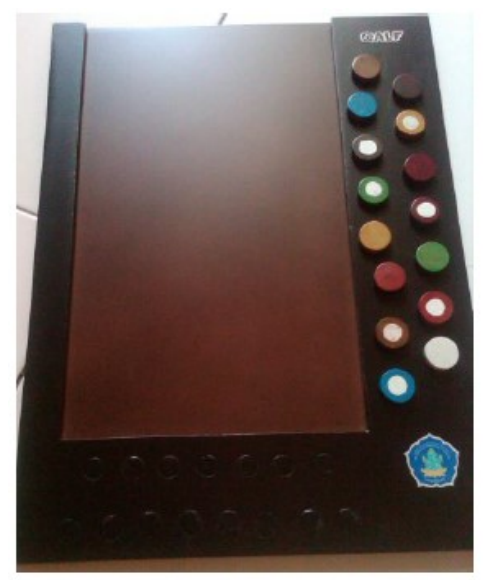

Figure 2. The Picture of Media Designed

Besides, the supporting materials were also developed based on the blueprint designed previously. They were organized in such a way to make it being able in giving flexibility for the students to use and help them to improve their reading ability. There were ten units designed as the supporting materials, identity, daily activities, school environment, family, house, clothes, animals, foods and drinks, parts of human body, and public places. In each unit, there were seven sheets, 1-3 vocabulary sheets, 2-3 filling the blank sheets, 2 comprehension sheets. It was designed with those varieties of sheets in each unit in order to help the students in that level understanding the vocabularies first, then being able to use those vocabularies in a text, until being able to comprehend a text. Totally, there were 70 papers designed as the supporting materials for one year. Those materials were printed by using hard paper to make them thicker and easy to be inserted in the media.

At the beginning the materials were supported by colorful cartoon pictures. But along the process of designing the materials, based on the suggestion of the first supervision, the cartoon pictures should be changed by using real pictures to make it more authentic. Because the pictures were still printed with colors, it still looked attractive and eye catching for students in that level. The following pictures show the supporting materials designed. 


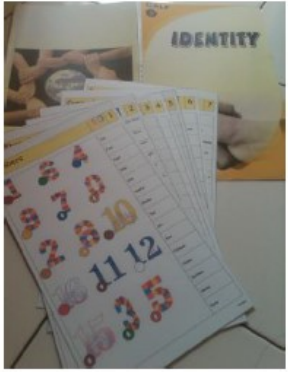

UNIT 1

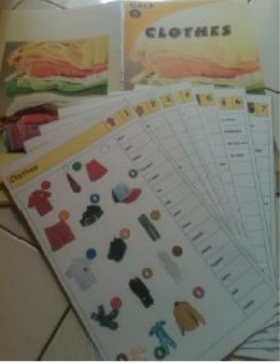

UNIT 6

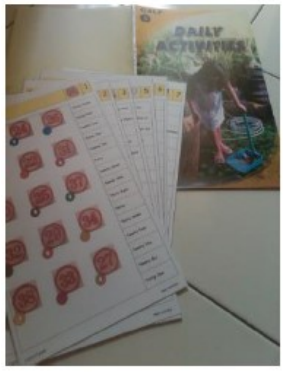

UNIT 2

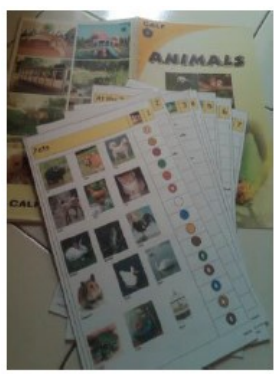

UNIT 7

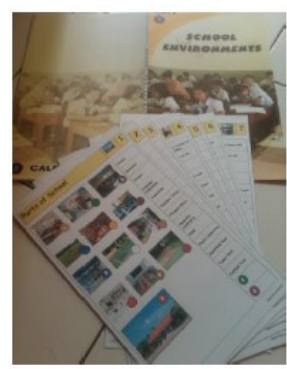

UNIT 3

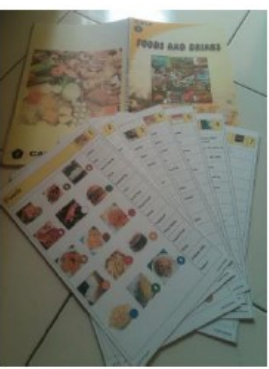

UNIT 8

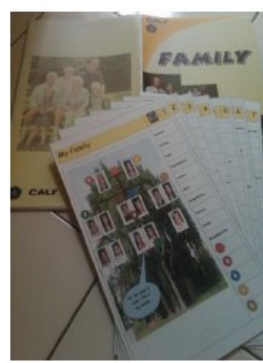

UNIT 4

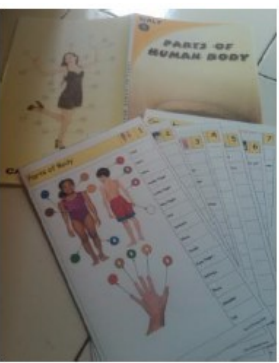

UNIT 9

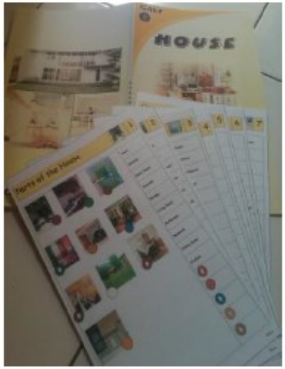

UNIT 5

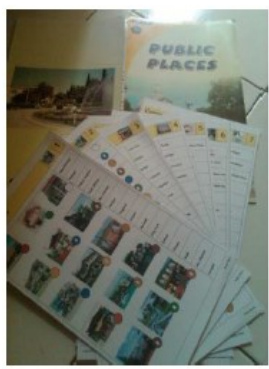

UNIT 10

Figure 3. The Picture of Supporting Material Designed

There were two experts who became the judges of this study, one is a lecturer of educational technology, and another one is a lecturer of English education. Those two judges judged the media developed based on the rubric designed by the writer. The rubric was based on the indicators in syllabus used in those settings, the criteria of good media by Zaman \& Eliyawati (2010), and the criteria of good material by Tomlinson. There were also three items that should be filled by the two judges; they were the general comments toward the media developed, the weaknesses of the media developed that should be minimized, and the strengths of it that should be defended.

From the rubric filled by the first and second judge, it was found that all the items which were based on the indicators in syllabus used in those settings were very computable. It mean that, the media and the supporting material included all aspects of indicators, the activities of understanding very simple descriptive text with topics: identity, daily activities, school environment, family, house, clothes, animals, food and drinks, parts of human body, and public places, which should be achieved by students of grade five of elementary school in one year. Besides, the media and supporting material designed could give good chances for students to be active in understanding very simple descriptive text with those topics.

The results of the rubric were analyzed to know the experts' opinion regarding to the media. That results from the criteria of syllabus, good media, and good materials then were calculated and categorized into one of the following rating scales: Excellent Media, Good Media, Average Media, Below Average Media, and Poor Media. The results of the rubric filled by the experts can be seen in Table 1 .

Table 1. The Result of Rubrics Filled by Experts

\begin{tabular}{|c|c|c|}
\hline Experts & Score & Rating \\
\hline First Expert & 307 & Excellent Media \\
\hline Second Expert & 316 & Excellent Media \\
\hline
\end{tabular}


In line with the results of rating the media designed, generally, it was said that the media designed was already good to support the activity of the students to learn. It was also said that, in general, the media designed had meet the demand of criteria of visual and dimension media in which its use had also already meet the demand of psychology and technological foundation. In relation with supporting material, the use of coloring pictures was already good which appropriate for the level of the students that still in the level of concrete operational. It was also said that the design of covers were already attractive and good. It was also added by the first judge about how to use the media in real situation. It was suggested that the media developed could be used as a tool or a strategy or even a technique in teaching.

\section{CONCLUSION}

The media could be developed by conducting several procedures, preliminary observation, syllabus analysis, library research, media development, experts' judgment, and field test. From those procedures, it was found that other kinds of strategy and media are needed in that school setting in helping the students being active in learning. Besides, the media which can help the fifth grade students of elementary school in Buleleng District to improve their reading competency is a media that: meet all the requirements of syllabus, good media, and good materials. It was also found that the media and supporting materials were designed based on the criteria of syllabus, good media and good materials and it was began by designing the blue print, designing media and supporting materials, being judged by the experts, and being revised. From the judgments of the experts, the media and supporting materials were categorized as excellent media.

\section{REFERENCES}

Afiatin, T. (2007). Pembelajaran Berbasis Student-Centered Learning. Psychology Faculty of Gajah Mada University. Available in www.inparametric.com . Downloaded on October $29^{\text {th }} 2010$

BSNP. (2006). Panduan Penyusunan Kurikulum Tingkat Satuan Pendidikan Dasar dan Menengah. Badan Standar Nasional Pendidikan

Carlton, M. (2003). Motivating Learning in Young Children. The National Association of Schools Psychologist

Killen, R. (1996). Effective Teaching Strategies: Lessons from Research and Practice. Social Science Press: Australia

Moats, L C. (1999). Teaching Reading Is Rocket Science: What Expert Teachers of Reading Should Know and Be Able to Do. A Union of Professionals

Muhaimin, S. \& Prabowo, S. L. (2008). Pengembangan Model KTSP pada Sekolah dan Madrasah. PT. RajaGrafindo Persada: Jakarta

Pang, E. S. et al. (2003). Teaching Reading. International Academy of Education. Available in http://www.curtin.edu.au/curtin/dept/smec/iae

Rahardjo, A. I. \& Pongtuluran, A. (2001). Students-Centered Learning: The Urgency and Possibilities. Petra Christian University: Surabaya. Downloaded on October $28^{\text {th }} 2010$

Riana, C. (2007). Komputer dan Media Pendidikan di Sekolah Dasar. Available in http://matemania.wordpress.com . Downloaded on October $28^{\text {th }} 2010$

Ruis, N. et al. (2009). Instructional Media: Supplement Module MGMP BERMUTU. Ministry of National Education: Indonesia 
Scott, W. A. \& Lisbeth H. Ytreberg. (1990). Teaching English to Children. Longman: London

Soekartiwi. (1996). Rancangan Instruksional. PT. RajaGrafindo Persada: Jakarta

Sugiyono. (2009). Metode Penelitian Kuantitatif, Kualitatif, dan R\&D. Alfabeta: Bandung

Zaman, B. \& Eliyawati, C. (2010). Media Pembelajaran Ana Usia Dini. Pengembangan Media Pembelajaran Taman Kanak-Kanak. Indonesian University of Education: Jakarta.

Tomlinson, B. (2011). Materials Development in Language Teaching ( $2^{\text {nd }}$ Edition). Cambridge University Press: Cambridge. 